\title{
PROFESSOR SCHEPPELE'S MIDDLE WAY: ON MINIMIZING NORMATIVITY AND ECONOMICS IN SECURITIES LAW
}

\author{
WiLliam T. AlLEN*
}

\section{INTRODUCTION}

In her ambitious critique of securities disclosure law, Professor Kim Scheppele seeks to attack a utilitarian account of, and prescription for, that law. ${ }^{1}$ She seeks, as well-and this is what makes her contribution ambitious-to offer an alternative way to create, and a different standard to criticize, legal rules than the method offered by the utilitarian paradigm. Her account of, and prescription for, securities disclosure law derives from a contractualist approach to rule formulation and criticism. Her approach is inspired by, but somewhat different from, that employed by John Rawls in his famous work, A Theory of Justice. ${ }^{2}$

On a practical level, Professor Scheppele offers criticism of the current Supreme Court law on insider trading reflected in Chiarella $v$. United States ${ }^{3}$ and Dirks v. Securities Exchange Commission. ${ }^{4}$ Her policy recommendation is that federal disclosure law should recognize a duty to disclose nonpublic information or abstain from trading in securities whenever a market participant has access to information that is not accessible to all other participants in the market. She sees her proposal as differing from current law in that under her rule it would not matter whether one with nonpublic information received it as part of a relationship that implied confidence or knew that his or her receipt of the nonpublic information was made possible by a breach of trust.

I begin by recognizing that this article is a pleasure to read. It is lucid, knowledgeable, textured, and innovative. The paper represents an imaginative effort to combine the method of Rawls (and others) with some available empirical data on risk preferences, and to apply that learning to problems of disclosure law. It thus enjoys an uncommon scope and breadth. Ultimately, however, for the reason discussed below, I find Professor Scheppele's critique of the existing Supreme Court law governing securities disclosure unconvincing. Perhaps more basically, I remain skeptical that the method employed by the article offers what its author hopes it can: a technique to generate specific legal

Copyright (C) 1993 by Law and Contemporary Problems

* Chancellor, Delaware Court of Chancery.

1. Kim L. Scheppele, "It's Just Not Right": The Ethics of Insider Trading, 56 LAw \& CONTEMP. PROBS. 123 (Summer 1993)

2. JOHN RAWLS, A THEORY OF JUSTICE (1972).

3. 445 U.S. 222 (1980).

4. 463 U.S. 646 (1983). 
norms that is explicitly concerned with distributional consequences of rules while avoiding messy, inherently contestable valuations of their "fairness."

My comments address only the more general aspects of Professor Scheppele's paper. They fall under two general headings. First, I offer a single basic criticism of the article's substantive critique of existing disclosure law. That criticism is premised on my contention, which Professor Scheppele may not sufficiently recognize, that transacting on markets, rather than face to face, has important moral implications. Second, I discuss briefly the utility of the "contractualist thought-experiment" method that Professor Scheppele employs. This method strikes me as a seductive but ultimately delusional way to try to convert moral questions into empirical questions. It has, however, an important value: It forcefully asserts to those who construct and those who criticize legal rules that the welfare of the least powerful should be of especial concern to the law; that ultimately our legal order is a constituent part of our moral universe; and that our system of legal rules must ultimately conform with the dominant moral sentiments of the age if the law is to achieve a productive balance between dynamic change and social stability.

\section{II}

\section{SUBSTANCE AND METHOD}

Professor Scheppele begins by questioning the principles offered to explain the law that requires a corporate insider to disclose material, nonpublic information or refrain from trading in the company's stock. ${ }^{5}$ She rejects a law and economics explanation, which holds that since such information is not acquired through private investment, it does not warrant property status and should therefore be disclosed to foster efficiency in stock prices. In the alternative, she offers fairness as a justification for the existing rule and for an extension of it. But "fairness," the writer recognizes, is a conclusion that can be vague and fuzzy, and has been criticized on that basis. ${ }^{6}$ Implicitly conceding the strength of this criticism, the article attempts to give specific content to the term "fairness," to free it from the charge that it is merely a "fuzzy" conclusion. To do this, the author employs a contractualist technique that asks what rule regarding disclosure would be freely accepted by persons acting ex ante, who possessed no knowledge of whether they were likely to be possessors of material, nonpublic information or transactors without such knowledge. She asserts that if we were somehow to find ourselves in this quasi-original position, ${ }^{7}$ we-the actual people located in this culture now-would adopt a rule that requires

5. Scheppele, supra note 1 , at 126.

6. Scheppele, supra note 1 , at 125.

7. I call this a quasi-original position because the hypothetical persons involved are behind only a limited veil of ignorance. While they do not know what property they own, what information they have, or what prospects they enjoy, they are, in other respects, our actual selves possessing the attitudes, beliefs, biases, etc., of all people in the United States now. 
disclosure of all "deep" secrets (those that the other party has no means of knowing). She calls this an equal access rule. ${ }^{8}$

As I understand the perspective of the law and economics scholars whom Professor Scheppele opposes, it would assert that rational persons in this quasioriginal position would adopt a rule that would tend to increase efficiency or maximize wealth, because the creation of more wealth will increase the likelihood that both sides of any transaction can benefit from transacting. Professor Scheppele asserts, commonsensically, that people are concerned with distributional effects when their own interests are involved. Everybody wants a share of the gains made in transactions to which they are a party. She posits that, ex ante, such creatures would only consent to a legal regime that affords everyone a chance for such participation. She asserts that the equal access rule is the only disclosure rule that such persons, existing behind her partial veil of ignorance, would accept freely. In so concluding, she assumes or believes that residents of the United States are, to this extent, risk-averse; that psychologically, they will identify with outsiders in insider trading transactions. That is, she implicitly supposes that they would not see in information asymmetry a chance to exploit others (or the situation) for a profit, but, rather, a risk to their own ability to recover any part of the value of the information. Perhaps she is correct about this. But if so, it would seem to be a consequence of particular psychological characteristics, not "rationality." In all events, she cites no data showing that such psychological characteristics are shared by even a majority of U.S. residents, thus falling short of the improbable burden of this method: to produce only rules to which all would agree.

\section{A. The Moral Significance of Trading on Markets}

Professor Scheppele's criticism of the existing Supreme Court law of disclosure is rooted in a series of cases stretching back into the nineteenth century. These cases are meant to show that the Supreme Court misread history when, in Chiarella, it indicated that an affirmative duty to disclose information has not been generally recognized by the common law. ${ }^{9}$ The criticism is, I suggest, fundamentally flawed. While the cases cited, and others, ${ }^{10}$ established that courts have, in some settings, imposed liability for failure to make a disclosure, they are inapposite, when the purchase and sale transaction is one that occurs on a large public market. Trading on such a market has legal and (perhaps more importantly for the article's legal reform purpose) moral implications that Professor Scheppele does not sufficiently recognize.

The seller or buyer of stock on one of the regulated markets has no relationship at all with the particular entity on the other side of that transaction. The transaction is completed through impersonal agencies matching anonymous

\footnotetext{
8. Scheppele, supra note 1 , at 125.

9. Chiarella, 445 U.S. at 227.

10. See, e.g., Cummings v. Dusenbery, 338 N.E.2d 575 (Ill. App. Ct. 1984).
} 
buy and sell orders. Only price and number of shares matter to those involved. Unlike the face-to-face negotiation, the seller cannot induce the buyer to act or facilitate the sale. The buyer cannot rely, to any extent, upon the seller's conduct. They do not know each other. This complete absence of a social relationship between buyer and seller has pertinence, it seems to me, if one wants to define what moral obligations, if any, persons in this culture bear towards each other.

It may be answered that the lack of any meaningful relationship between anonymous market participants cannot conclusively establish that anonymous market actors have no special moral relationships (upon which one can build a legal duty). I may have no prior relationship with pedestrians as I drive my car down a busy road, but I plainly do owe moral and legal duties to them. They are persons who might foreseeably be injured should I fail to exercise ordinary care. This duty to strangers is morally quite intuitive; the power to harm gives rise to the duty to take care. Can some principle like that which accounts for a driver's duty to strangers justify a buyer or seller's duty to disclose relevant "deeply secret" information to a public market? I would not think so, because (and here I am on a very different wavelength than Professor Scheppele) I do not accept that those who trade on an impersonal market are themselves injured by another market participant's failure to disclose inside information or to refrain from trading.

This is because one buying or selling on a large active market would buy or sell at the market price whether or not the insider traded. From this supposition, one could conclude, as I do, that the "insider" is causing no financial harm to those on the opposite side of the transaction, whomever they may be. In theory, the contrary is the case. If the "insider" is buying, she will tend to push the price up, to the marginal benefit of contemporaneous sellers, and if she is selling, she will theoretically tend to push down the price.

Thus, while I share the intuition that there can be something wrong with "insider" trading on a public securities market, I remain unconvinced that it is morally wrong because it causes special financial injury to those on the opposite side of such transaction. It does not. Rather, when one thinks about the stock price consequences of insider trading, one might conclude that those disadvantaged by such trading are persons who are on the same side of parallel transactions at the same time. The insider trades, if large enough, will tend detrimentally to affect the price at which their transactions are completed. But while those on the same side of buy-sell transactions may theoretically be affected by insider trades, they will be affected similarly by any buy or sell transaction of the same dimensions. Impact upon them is not itself enough to support a conclusion that they have been wrongfully affected. To justify that conclusion, we must locate a norm-such as the due care norm in the auto accident example-that will mark that conduct as wrong.

What norm do we assume if we intuit that insider trading is morally wrong? I suppose that there are, arguably, two such norms, one that applies to issuers and one that applies to individuals in possession of "inside" information. Both 
are premised upon the existence of a relationship that we see as deserving of protection. Insofar as individuals are concerned, I suppose that the core of the insider trading offense is the misappropriation of proprietary information belonging to another. Thus, in using information for his personal benefit that was supplied to him for a special, limited purpose, the printer in Chiarella ${ }^{11}$ might be seen as misappropriating property of another; of breaching a duty of loyalty to his employer and derivatively to his employer's customer. While the issuing corporation may itself experience no direct financial injury as a result of such misuse of its nonpublic information, equity will act to police the relationship in which the issuer entrusted its nonpublic information to another. ${ }^{12}$

A legal rule designed to enforce the limitations on use or disclosure of nonpublic information implicit in its dissemination would not extend to the issuer's own use of its material nonpublic information to purchase its stock on a public market. ${ }^{13}$ Thus, if we wish to explain or justify a disclosure-or-abstain rule for issuers buying their own stock, we must identify a different norm. I suggest that the norm that shapes our intuition about that subject is the norm that defines the relationship between the corporation and its shareholders. That relationship-and the loyalty that we have long held that it implies ${ }^{14}$-would provide an arguable moral basis, within the liberal model of society as made up of autonomous individuals, to impose an obligation on an issuer to refrain from voluntarily buying its own stock unless full disclosure of material information had been made. ${ }^{15}$

Thus, because Professor Scheppele's analysis does not sufficiently consider the moral or economic implications of trading on a public market, it is, to that extent, not completely persuasive. In discussing the duties of the buyer of stock on a public market, the Supreme Court ignored cases dealing with implied covenants or fraud in face-to-face sales transactions. In so doing, it correctly acknowledged, implicitly, the significance of trading on markets.

11. Chiarella, 445 U.S. 222.

12. See Brophy v. Cities Serv. Co., 70 A.2d 5 (Del. Ch. 1949).

13. The issuer's sale of stock, even when through a public underwriting, is much more like a face-toface transaction than an anonymous market transaction. The buyer of stock from an issuer, whether on a market or privately, like the buyer of goods in a face-to-face transaction, inevitably must rely upon the statements of the seller-its financial reports especially-in making the investment decision. Thus, if we search for the moral principle underlying disclosure rules that apply to issuers selling their own securities, we need go no further than the norm of truth telling and candor in face-to-face dealings.

14. That duty of loyalty is itself narrow. The corporation does not, for example, owe its stockholders any special responsibility with respect to transactions with shareholders on the corporations' various product markets.

15. I express no opinion on the question whether the common law of directors' duties does require the board to restrain the corporation from all dealings in its own stock on an impersonal public market unless all material information has been disclosed. I mean simply to identify the relational norm upon which such a result might be constructed. 


\section{B. The Contractualist Method}

The broader aim of Professor Scheppele's article is to demonstrate the utility, in the formulation of specific legal rules, of a technique that she offers as an alternative to that which she sees as the narrow and limited approach of legal scholars in the thrall of neoclassical economics. She wants to call our attention to an alternative to the utilitarian approach. In its most basic aspect, utilitarianism is concerned, she says, with the maximization of something - wealth often, sometimes happiness or utility-but not with its distribution. Those legal scholars bitten by this old bug are unconcerned about issues of the distributional effects of rules, and thus about issues of fairness. ${ }^{16}$ Indeed, she alludes to the materialist statements of some who, confusing ambiguity with incoherence, seem to deny the meaningfulness of such terms as fairness (and, one would suppose, justice).

I think she sees this narrow vision of law as stultifying and inhumane, as morally obtuse. She means to show us a way out without leading us into a swamp of ambiguity. She offers a technique to generate specific legal rules that aims frankly at distributional fairness, but that does so in a way that, if not exactly empirical and positive, is perhaps close. She employs the technique of constructing a "thought-experiment." This oxymoron reflects the unstable ground between empiricism and metaphysics that Professor Scheppele's methodology occupies. For the reasons discussed below, I am unpersuaded that her method can succeed in "objectifying" fairness by removing from that label the contestable element of moral judgment. For me, that is not a fatal criticism, as I have never supposed that ambiguity and contestability could be completely removed from legal discourse. But I do suppose that if the contractualist technique fails to offer an escape from "fuzziness," Professor Scheppele will have failed in one of her goals.

Professor Scheppele begins her method discussion by suggesting that the best legitimating characteristic of a legal rule is the fact that it has been agreed upon by all who will be bound by it. This, of course, could be contested, but in the modern Western world of liberal individualism, it does seem a proposition to which many would assent. Since it would appear that, for reasons of technology if for no other, we cannot practically create legal rules by a process of actual consent ${ }^{18}$ Professor Scheppele suggests, as the foundation of legal rules, that

16. But see Guido Calabresi, The Pointlessness of Pareto: Carrying Coase Further, 100 YALE L.J. 1211 (1991).

17. Scheppele, supra note 1 , at 153 .

18. The method employed posits that the best rule is the rule to which all U.S. residents would consent ex ante. If one is moderately practical, she might suppose that there is considerable chance that there are very few rules (and none concerning civil liability for disclosure in connection with transactions on public securities markets) to which literally all actual persons now in the United States could be expected to agree if we could slip them behind a veil of ignorance. Presumably, a weaker version of the method would accept consent by majority rule, but that version would give up an important concern of Professor Scheppele-with the consent of the least advantaged-and is not the version that Professor Scheppele pursues. 
rule-making elites imagine-aided by the best available empirical data-rules that could find complete acceptance.

One might note the common ground that this model shares with the utilitarian approach. In fact, I suppose that economist-inspired legal scholars would not argue too much with Professor Scheppele concerning the priority of consent as a legitimating force in law. Neoclassical economics is rooted in the same liberal suppositions as is her own vision. Indeed, the standard Pareto efficiency definition assumes, generally, that free consent to voluntary transactions is the road to human betterment. Professor Scheppele's liberalism departs from the liberalism of the Chicago School version of the law and economics movement, however, in two important respects. First, she is concerned with choice in the formation of background legal rules, whereas the liberal economist is concerned with individual choice in the structure and effectuation of transactions. Second, and importantly, she is concerned with the distributional consequences of legal rules (thus her insistence that all agree), whereas the neoclassical economist, for the most part, stipulates the irrelevance of distributional consequences.

The notion that society can helpfully be viewed as the result of a hypothetical social contract is, of course, old and productive. As employed by Professor Rawls, for example, this perspective engenders fruitful and challenging speculation. In his effort, Rawls assumes away every aspect of personhood except rationality ${ }^{19}$ and implicitly makes some debatable assumptions about risk aversion. From these assumptions a very active mind can (and did) construct a fascinating vision. Professor Scheppele is a sociologist, not a philosopher. Professionally bound in some way to empiricism, she employs the contractualist method in a modified way. While she posits actual persons making decisions about legal rules, and not, like Rawls, the moral essence of persons. Still, like Rawls, a large part of her conclusion follows from her suppositions about how such persons would choose. She supports her intuitions about equal access to material information with the only study available ${ }^{20}$ and her intuitions appear consistent with it, at a rather high level of generalization.

In assessing this effort, it is fair to ask, first, whether the method of the "thought-experiment" is likely to supplant stark utilitarian calculus as a means to generate or criticize legal rules concerning securities regulation. My own evaluation is that in no event can it remove utilitarian concerns from our thinking about securities law.

Consider the equal access rule that the article advances. In the world of affairs where the consequences of ideas on real people can be sharp and immediate, a rule-making agency considering the "thought-experiment" would

19. As to the boundedness of human rationality, in fact, see, e.g., Amos Tversky \& Daniel Kahneman, Rational Choice and the Framing of Decisions, in THE LIMTTS OF RATIONALITY (Karen S. Cook \& Margaret Levi eds., 1990); John Elster, When Rationality Fails, in THE LIMITS OF RATIONALITY (Karen S. Cook \& Margaret Levi eds., 1990).

20. Scheppele, supra note 1 , at $\mathbf{n} .130$ and accompanying text. 
pause on the assertion that all would agree to a rule of equal access, if somehow we could be polled before we acquired property interests or expectations. That core assertion is itself, of course, eminently contestable. It is counter-factual and can be neither proven nor falsified. In the absence of certainty about the core assertion, it is quite likely that any agency that considers the contractualist "thought-experiment" methodology would need somehow to assess the likelihood that unbiased minds would, as the article urges, freely adopt only the equal access rule. Moreover, because no agency can have perfect information about hypothetical preferences, one would need to consider as well the likely effects on the efficiency of securities markets that adoption of such a rule would occasion. The efficiency costs of the rule, discounted by the risk of incorrectly concluding that the equal access rule would be the actual (I mean hypothetical) preference, would be relevant. ${ }^{21}$ If one only has a rough intuition about preferences, however-which I take to be the case here-the efficiency impacts of alternative rules would necessarily assume very major importance to a rulemaker, as a consequence of that uncertainty.

While Professor Scheppele does try to ground her intuitions on risk-taking in an empirical study, in fact, we will never know with great confidence what the actual humans who make up this society would, in an unbiased condition, each prefer in the way of legal rules. Thus, I cannot accept that the contractualist methodology can ever make utilitarian concerns wholly irrelevant to the process by which securities disclosure law is formulated. Nor do I believe that this method can serve its other goal: to decouple "fairness" from the inevitably contestable and value-laden arguments that seek, in any particular context, to justify that conclusion.

\section{III}

\section{CONCLUSION}

The contractualist method seeks to avoid both the stark utilitarianism of neoclassical economics and the messy, contestable nature of "moral reasoning" in law. It does this by trying to convert the search for fairness into something like an objective inquiry: What is the rule that in an unbiased state we would all choose? While this is not really an empirical question, it is one that empirical social science data would be helpful in answering (for example, what are our values? What is our psychic attitude towards risk? How do we relate to the pain of others?). Thus, this method seems to hold out the hope of converting moral questions into positive questions: The preferred rule is the one we would all choose in the absence of bias, and we can perform empirical studies to help us discover how we would choose. In a positivistic age, that alchemy might be

21. I assume, arguendo, that the efficiency costs of the equal access rule, such as they may be, would be regarded as appropriately incurred where the agency correctly concludes that that rule would be preferred by all if a referendum could be held behind a partial veil of ignorance. 
expected to exert appeal. But that appeal is false. Empirical inquiries are unlikely to tell us what our disclosure law should be. ${ }^{22}$

In attempting to objectify fairness, in order to meet arguments that the concept is too amorphous to have legitimacy in legal discourse, Professor Scheppele gives away too much to the critics she would challenge. In the process, she creates a concept of fairness that strikes me as being too narrow to have great utility. I suppose there is a better response to those who regard the concept of fairness as too vague, empty, or meaningless to play a constructive, legitimate role in legal discourse. That response would deny the validity of the criticism frontally. It would assert that our law is inherently both a utilitarian system for facilitating and structuring wealth creating transactions, and a system of rules of behavior premised on widely shared moral or ethical beliefs. Evaluation of the fairness of legal rules is an inescapable part of the evaluation of the quality of the legal system by the citizens who are subjected to that system. Thus, it cannot be the case that courts, when they are confronted with the responsibility of interstitial rule formulation or modification, as they inevitably will be from time to time, may not legitimately take fairness concerns directly, albeit cautiously, into account.

The perception of the success of our legal system in achieving justice is not an irrelevant concern. It is central. Periods of social unrest make this clear. Inquiry into the justice or fairness of the system, or of a rule in the system, is not meaningless talk in which every statement counts equally. Discussion of the fairness of a rule takes place at a specific time and place, in a certain culture, with its history, traditions, and shared beliefs, and in a specific language, with its shared meanings and history. This social context provides a basis for people to construct and criticize arguments concerning the fairness of proposed rules. Furthermore, it provides a basis for others to evaluate the validity of those claims. This type of discussion will not succeed in finding an objective referent for concepts of justice or of fairness. But, for those who have come to accept the inevitability of ambiguity in our social life, the fact that conclusions concerning fairness will, in principle, be contestable does not justify excluding this important value from our judicial process. Nor does it, I suppose, necessitate resort to the innovative technique that this article presents in order to answer claims that the concept of fairness is empty and constrains courts too little.

Our law has long recognized that fairness concerns can sometimes trump the claims of clear legal rules. Indeed, that is much of what equity has been all about for $\mathbf{4 0 0}$ years. Consider, for example, as I recently had occasion to do, the development of the law of unconscionable contracts. ${ }^{23}$ For well over 200 years, courts of equity have, in the absence of fraud, refused to enforce or have

22. Empiricism is of great instrumental utility in the law, as a way of informing us how best to achieve some noncontroversial value. At the risk of stating the obvious, I note, however, that by their nature, disputes of ultimate value cannot be resolved by empirical investigations.

23. Ryan v. Weiner, 610 A.2d 1377 (Del. Ch. 1992) (holding that shocking and oppressive nature of transaction required recission). 
rescinded contracts for the sale of land that were formally binding in every respect but were so oppressive as to "shock the conscience of the court." This doctrine of unconscionability coexisted with the development of the liberalutilitarian mindset, and continued to exist through the high tide of that mindset in the neoclassical world of the nineteenth century. It continues to this day and, indeed, has been expanded by statute in practically every state to reach contracts for the sale of goods.

The term "unconscionable" is precisely as vague as is the term "fair." The terms are, of course, conclusions and abstractions. They are not empty vessels into which any meaning can be poured, however. They are part of our language, and of our moral and legal traditions. We cannot escape these words with blurred edges. If our law is to satisfy its basic mission, we must use the concepts behind them. Their use in our legal system is legitimated by the process of construction and of argumentation that a court employs in reaching and stating its conclusions. Our traditions, our political institutions, and the shared professional understanding of lawyers and judges constrain and delimit the use that may legitimately be made of these abstractions. I believe, however, that Professor Scheppele is mistaken in her hope that we can escape the ambiguity that they entail, the ambiguity that is the special burden of our age, by resort to the contractualist thought-experiment.

It is difficult not to sympathize with any observer who seeks to remind us that law is not only a practical institution concerned with welfare, but it is a reflection of and indeed a constituent part of our moral universe. Some of us energized by the productive insights generated by economics might, I suppose, usefully be reminded of that fact from time to time. I am unconvinced, however, that the contractualist method employed in Professor Scheppele's article can do more than provide an orientation that allows those who construct and those who criticize legal rules to identify, imaginatively and sympathetically, with the least powerful of those affected by legal rules. If it did no more, this reminder would justify the substantial scholarly effort reflected in Professor Scheppele's fine article. 